\title{
Evaluasi Nutrisi Silase Kultivar Baru Tanaman Sorgum (Sorghum Bicolor) dengan Penambahan Legum Indigofera sp. pada Taraf Berbeda
}

\author{
Nutrient Silage Evaluation of New Sorghum (Sorghum Bicolor) Cultivation with Addition of Legum Indigofera sp. at \\ Different Levels
}

Y L A Holik, L Abdullah, P D M H Karti

Corresponding email:

yayangholik@gmail.com

Departemen Ilmu Nutrisi dan Teknologi Pakan, Fakultas Peternakan, Institut Pertanian Bogor (Bogor Agricultural University/IPB University)

\section{ABSTRACT}

Sorghum is a source of fiber which is very potential to be cultivated and developed for forage production. Silage is a forage preservation method based on lactic acid fermentation under anaerobic conditions. Indigofera sp. is a tropical leguminous trees source with high protein content. Indigofera has an advantages in production and quality. The research was purposed to analyze the quality of sorghum varieties with the addition of Indigofera sp. different. Materials used in this study include Hybrid 20 sorghum plants, sorghum plants 12FS9006, sorghum plants 13FB7001, sorghum plants 12S49001, Indigofera sp. Plants with levels $(0 \%, 10 \%, 15 \%$, and $20 \%)$, EM4 and molasses. The equipments for making silage consisting of coper to chop up sorghum plants, scales, sprayers, shovels, sorghum compaction equipment, silos in the form of plastic buckets with plastic bags. The data was analyzed a multiple regression data normality test using Independent T-method. The results showed that silase sorghum 12 FB7001 had higher water contenct, ash content and crude fat, whereas sorghum hybrid 20 had higher protein content and crude fiber. Sorghum $12 \mathrm{FS} 9006$ produced good quality silage (NH3, VFA, KCBK, and KCBO). It is concluded silage quality of the four sorghum cultivars than $0 \%, 10 \%$ and $20 \%$ levels.

Key words: digestibility, Indigofera sp., quality, silage, sorghum cultivars

\section{ABSTRAK}

Sorgum merupakan hijauan sumber serat yang sangat potensial dibudidayakan dan dikembangkan pada lahan. Silase adalah metode pengawetan hijauan berdasar pada fermentasi asam laktat di bawah kondisi anaerob. Indigofera sp. merupakan leguminosa pohon tropis sumber protein hijauan atau konsentrat hijau yang memiliki keunggulan dalam produksi dan kualitasnya. Penelitian ini bertujuan untuk menganalisis kualitas nutrien silase dari berbagai varietas sorgum dengan penambahan taraf Indigofera sp. yang berbeda. Bahan yang digunakan dalam penelitian ini meliputi tanaman sorgum Hybrid 20, tanaman sorgum 12FS9006, tanaman sorgum 13FB7001, tanaman sorgum 12S49001, tanaman Indigofera sp. dengan taraf (0\%, 10\%, 15\%, dan 20\%), EM4 dan molasses. Alat yang digunakan meliputi peralatan untuk pembuatan silase yang terdiri dari coper untuk mencacah tanaman sorgum, timbangan, sprayer, sekop, alat pemadatan sorgum, silo berupa ember plastik dengan kantong plastik. Analisis data silase tanaman sorgum dan Indigofera sp. dilakukan menggunakan uji normalitas data regresi berganda menggunakan uji Independent T-Test. Hasil penelitian menunjukkan, bahwa silase sorgum 13FB7001 memiliki kadar air, kadar abu dan lemak kasar lebih tinggi, sedangkan silase sorgum Hybrid 20 memiliki kandungan protein kasar dan serat kasar yang lebih tinggi. Kultivar sorgum 12FS9006 menghasilkan silase yang berkualitas baik secara fermentatif (pH, N-NH3, VFA, KCBK, dan KCBO). Kesimpulan hasil penelitian level pemberian Indigofera sp. 15\% cenderung memberikan kualitas silase keempat kultivar sorgum yang lebih tinggi dibandingkan level 0\%, 10\% dan 20\%.

Kata kunci: Indigofera sp., kualitas, kecernaan, kultivar sorgum, silase 


\section{PENDAHULUAN}

Produktivitas ternak ruminansia sangat tergantung pada penyediaan hijauan pakan sebagai sumber nutrisinya, namun ketersedian pakan hijauan di Indonesia sangat fluktuatif. Pada musim hujan jumlahnya akan melimpah, sedangkan pada musim kemarau hijauan akan menurun atau sulit didapatkan, oleh karena itu diperlukan teknologi pengawetan untuk mengatasi masalah tersebut. Salah satu diantaranya melalui teknologi pengawetan hijauan dengan proses fermentasi, yaitu silase. Kelebihan hijauan selama musim hujan dapat disimpan sebagai silase untuk digunakan ketika paceklik tiba (Reiber et al. 2010). Silase merupakan awetan basah segar yang disimpan dalam silo, sebuah tempat yang tertutup rapat kedap udara, hijaun pada kondisi anaerob. Pada suasana anaerob tersebut akan mempercepat pertumbuhan bakteri untuk membentuk asam laktat (Mugiawati 2013). Hijauan yang ideal digunakan sebagai silase adalah segala jenis tumbuhan atau hijauan serta bijian, terutama yang banyak mengandung karbohidrat, seperti rumput, sorgum, jagung, biji-bijian kecil, tanaman tebu, tongkol gandum, tongkol jagung, pucuk tebu, batang nanas dan jerami padi (Direktorat Pakan Ternak 2011).

Pembuatan silase terkadang dibutuhkan bahan tambahan (aditif) untuk meningkatkan proses silase, sehingga diperoleh silase yang berkualitas baik. Silase yang berkualitas baik antara lain ditandai oleh rendahnya $\mathrm{pH}$ yang dicapai selama proses silase dan tidak terjadi penurunan kulitas yang berlebihan pada hijauan yang dibuat silase. Utomo (2015) mengungkapkan bahwa silase merupakan hijauan segar yang disimpan dalam kondisi kedap udara (anaerob) dalam silo. Kondisi anaerob dapat diciptakan dengan cara pemadatan dan penutupan silo yang baik serta menciptakan suasana asam dalam silo. Kualitas silase tidak hanya cukup dilihat dari komposisi nutrisi yang terkandung didalamnya namun perlu diteliti dan diuji kecernaannya. Pengukuran kecernaan ini salah satunya dilakukan dengan teknik in vitro atau teknik rumen buatan, yaitu suatu percobaan fermentasi bahan pakan secara anaerob dalam tabung fermentor dan menggunakan larutan penyanggah yang merupakan saliva buatan.

Tanaman Sorgum (Sorghum bicolor) sangat potensial untuk dikembangkan di Indonesia dikarenakan tanaman sorgum toleran terhadap kekeringan dan genangan air, dapat berproduksi pada lahan marjinal, serta relatif tahan terhadap gangguan hama/penyakit (Sirappa 2003). Tanaman sorgum mempunyai potensi untuk dijadikan pakan ternak ruminansia khususnya pada bagian hijauan (batang dan daun) sebagai sumber seratnya. Perkembangan varietas sorgum (Sorghum bicolor) telah berkontribusi di bidang peternakan sebagai sumber pakan dengan berbagai tipe yang bisa dimanfaatkan diantaranya, jenis sorgum yang merupakan sorgum introduksi dari negara Australia yang tergolong ke dalam forage sorghum. Kultivar baru tanaman sorgum tersebut yaitu hybrid-20, 12 FS 9006, 13 FB 7001, dan 12 S49001. Menurut Nur'aini (2017) komposisi nutrien BETN dalam 100\% bahan kering sorgum utuh untuk varietas sorgum hybrid 20 , sorgum 12FS9006, 13FB7001, dan 12 S49001 sebesar 53,28\%, $52,90 \%, 53,54 \%$, dan $57,49 \%$.

Teknologi silase sorgum dengan penambahan Indigofera sp. sangan efektif dikembangkan, selain dapat digunakan untuk pengadaan pakan jangka panjang, juga dapat menghasilkan pakan dengan kualitas nutrien yang baik. Tanaman Indigofera sp. merupakan leguminosa pohon tropis dan memiliki kandungan nutrien yang baik. Abdullah (2014) menyatakan bahwa Indigofera sp. merupakan salah satu sumber protein hijauan atau konsentrat hijau karena memiliki keunggulan dalam produksi dan kualitasnya dibandingkan dengan legum lain. Ditinjau dari nutriennya, Indigofera sp. memiliki kandungan protein kasar yang dapat mencapai $24,42 \%$ $31,05 \%$ (Suharlina 2010). Silase pakan berbasis sorgumIndigofera menghasilan silase yang berkualitas tinggi baik secara karakteristik fisik (bau, warna, tekstur, kerusakan) maupun secara fermentatif ( $\mathrm{pH}, \mathrm{NH} 3, \mathrm{VFA}$, NDF, ADF dan total bakteri) (Telleng 2017). Penelitian ini bertujuan untuk menganalisis kualitas nutrien silase dari berbagai varietas sorgum dengan penambahan taraf Indigofera sp. yang berbeda.

\section{METODE}

\begin{abstract}
Alat dan Bahan
Peralatan untuk pembuatan silase terdiri dari coper, timbangan, sekop, alat pemadatan sorgum, silo berupa ember plastik ukuran $13 \mathrm{~kg}$ dengan kantong plastik. Bahan yang digunakan dalam penelitian ini meliputi tanaman sorgum Hybrid 20, tanaman sorgum 12FS9006, tanaman sorgum 13FB7001, tanaman sorgum 12S49001, tanaman Indigofera sp., EM4 dan molasses.
\end{abstract}

\section{Perlakuan}

Penelitian ini menggunakan 16 perlakuan dengan empat varietas sorgum yang terdiri dari sorgum Hybrid 20 (S1), sorgum 12FS9006 (S2), sorgum 13FB7001 (S3), sorgum 12S49001 (S4) dan penambahan Indigofera sp. kontrol level 0\% (G0), level 10\% (G1), level 15\% (G2), dan level $20 \%$ (G3) 


\section{Prosedur Pembuatan Silase}

Tanaman sorgum dipanen pada umur 90 hari batang, daun dan bulir. Setelah panen sorgum dilayukan selama 1 hari, kemudian dicacah dengan ukuran 3-5 cm. Pembuatan silase pada perlakuan kontrol, hijauan sorgum dicacah mengunakan coper dan dimasukan ke dalam ember plastik sampai padat sehingga tidak ada udara yang terperangkap di dalam. Campuran EM4, molases dan air dengan perbandingan antara 1:1:10 liter air disemprotkan ke dalam ember tersebut, setelah itu ditutup dan diikat dengan kantong plastik. Proses ensilase dilakukan selama 21 hari, kemudian pada perlakuan lainnya juga dilakukan prosedur yang sama dengan perlakuan penambahan taraf Indigofera sp. yang berbeda.

Pemanenan silase dilakukan setelah proses ensilase selama 21 hari. Selanjutnya dilakukan pengamatan sifat fisik berupa aroma, warna secara kualitatif, dan konsentrasi keberadaan jamur. Pengambilan sampel silase yang sudah bersih dimasukan ke dalam plastik. Sampel yang telah diambil dibagi menjadi dua bagian, yaitu sampel silase basah untuk langsung diuji $\mathrm{pH}, \mathrm{NH}$, dan VFA, dan sampel silase untuk dikeringkan. Sampel silase untuk dikeringkan. Silase sempel kering diperoleh melalui cara membungkus silsae dengan kertas buram dan dikeringkan menggunakan $60^{\circ} \mathrm{C}$. Silase yang sudah kering kemudian digiling dan dilakukan pengujian proksimat, pH, NH3, VFA, KCBK, dan KCBO.

\section{Analisis Data}

Analisis untuk data silase tanaman sorgum (Sorghum bicolor) dengan penambahan Indigofera sp. dalam penelitian ini adalah pengolahan data pada peubah kuantitatif yang dilakukan dengan menggunakan uji normalitas data regresi berganda menggunakan uji Independent T-Test menggunakan software IBM Statistic SPSS 20.

\section{Peubah yang Diamati}

\section{Kualitas fisik silase}

Pengukuran kualitas fisik silase dilakukan dengan pengujian sensori untuk peubah aroma, warna, dan keberadaan jamur.

\section{pH silase}

Pengukuran $\mathrm{pH}$, pengukuran dilakukan dengan silase yang baru dibuka ditimbang sebanyak $10 \mathrm{~g}$ (sudah di mixer) dan dicampur dengan $100 \mathrm{ml}$ aquadest kemudian dimasukkan ke dalam erlenmayer lalu dihomogenkan dengan menggunakan magnetic stirer selama 5-10 menit. Setelah aquadest dan silase tercampur, disaring untuk mendapatkan supernatannya. Kemudian diukur pH supernatan tersebut dengan menggunakan $\mathrm{pH}$ meter yang telah dikalibrasi pada larutan ber pH 4 dan 7 .

\section{Komposisi nutrien silase sorgum dengan penambahan Indigofera}

Analisis kadar air

Kadar air sampel silase dianalisis dengan menggunakan metode gravimetri. Cawan aluminium dikeringkan dengan oven pada suhu $130 \pm 3^{\circ} \mathrm{C}$ selama 15 menit kemudian didinginkan dalam desikator selama 10 menit. Sekitar 1-2 g sampel silase ditimbang ke dalam sebuah cawan alumunium yang sudah diketahui bobotnya (cawan harus dikeringkan dahulu dalam oven sebelum digunakan untuk penimbangan) kemudian dikeringkan dengan oven pada suhu $1{ }^{\circ} 5^{\circ} \mathrm{C}$ selama 3 jam, didinginkan dalam desikator dan ditimbang sampai diperoleh bobot yang konstan $(\leq 0,0005 \mathrm{~g})$.

Analisis kadar abu

Analisis kadar abu silase dilakukan dengan metode gravimetri. Cawan porselin kosong dan tutupnya dikeringkan dalam oven bersuhu $105^{\circ} \mathrm{C}$ selama 15 menit dan didinginkan dalam desikator. Cawan porselin kering tersebut ditimbang dan dicatat bobotnya sebelum digunakan. Sebanyak 3,0 - 5,0 gram sampel tapioka ditimbang di dalam cawan porselin tersebut dan dimasukkan ke dalam tanur listrik bersuhu $550^{\circ} \mathrm{C}$ sampai proses pengabuan sempurna. Setelah pengabuan selesai, cawan contoh didinginkan dalam desikator kemudian ditimbang. Penimbangan diulangi kembali hingga diperoleh bobot tetap.

\section{Analisis kadar protein kasar}

Analisis kadar protein silase dilakukan dengan metode Kjeldahl. Sebanyak 100 - 250 mg sampel dimasukkan ke dalam labu Kjeldahl kemudian ditambahkan dengan 1,9 $\pm 0,1 \mathrm{~g} \mathrm{~K}_{2} \mathrm{SO}_{4}, 40,0 \pm 10 \mathrm{mg} \mathrm{HgO}, 2,0 \pm 0,1 \mathrm{ml} \mathrm{H} 2 \mathrm{SO} 4$ pekat dan 2 - 3 butir batu didih. Sampel dipanaskan dengan kenaikan suhu secara bertahap sampai mendidih selama 1 - 1,5 jam sampai diperoleh cairan jernih. Setelah didinginkan, isi labu dipindahkan ke dalam labu destilasi dengan dibilas menggunakan 1 - 2,0ml air destilata sebanyak 5 - 6 kali. Air cucian dipindahkan ke labu destilasi kemudian ditambahkan dengan 8 - 10,0 ml larutan $60 \% \mathrm{NaOH}-5 \% \mathrm{Na}_{2} \mathrm{~S}_{2} \mathrm{O}_{3}$. Di tempat yang terpisah, 5,0 ml larutan $\mathrm{H}_{3} \mathrm{BO}_{3}$ dan $2-4$ tetes indikator merah metil - biru metil dimasukkan ke dalam erlenmeyer. Labu erlenmeyer kemudian diletakkan dibawah kondensor dengan ujung kondensor terendam di bawah larutan H3B03. Proses destilasi dilakukan sampai diperoleh sekitar 15,0 ml destilat. Destilat yang diperoleh diencerkan sampai 50,0 ml dengan akuades, kemudian dititrasi dengan larutan $\mathrm{HCl}$ 0,02 $\mathrm{N}$ yang telah distandarisasi sampai terjadi perubahan warna menjadi abu-abu. Volume larutan $\mathrm{HCl}$ 0,02 N terstandar yang digunakan untuk titrasi dicatat. Tahap yang sama dilakukan untuk larutan blanko sehingga diperoleh volume larutan $\mathrm{HCl}$ 0,02 N untuk blanko. Kadar protein dihitung berdasarkan kadar nitrogen ( $\mathrm{N}$ dalam g $100 \mathrm{~g}^{-1}$ bahan). 


\section{Analisis kadar lemak kasar}

Kadar lemak silase dianalisis dengan menggunakan metode soxhlet. Labu lemak dikeringkan di dalam oven suhu $105^{\circ} \mathrm{C}$ selama 15 menit, didinginkan di dalam desikator dan ditimbang sebelum digunakan. Sebanyak 1-2g sampel silase dimasukkan ke dalam selongsong kertas saring yang dialasi dengan kapas. Bagian atas selongsong kertas yang telah berisi sampel disumbat dengan kapas lalu dikeringkan dalam oven pada suhu tidak lebih dari $80^{\circ} \mathrm{C}$ selama \pm 1 jam. Selongsong kertas tersebut kemudian dimasukkan ke dalam alat soxhlet yang telah dihubungkan dengan labu lemak. Lemak sampel diekstrak dengan heksana selama \pm 6 jam. Heksana kemudian disuling sehingga diperoleh ekstrak lemak. Ekstrak lemak di dalam labu lemak kemudian dikeringkan dalam oven pada suhu $105^{\circ} \mathrm{C}$ selama 12 jam. Labu berisi lemak sampel kemudian didinginkan di dalam desikator lalu ditimbang bobotnya. Pengeringan diulangi hingga diperoleh bobot tetap.

\section{Analisis kadar serat kasar}

Sampel silase sebanyak $1 \mathrm{~g}$ dimasukkan ke dalam labu erlenmeyer $300 \mathrm{~mL}$, kemudian ditambah dengan $100 \mathrm{~mL}$ $\mathrm{H}_{2} \mathrm{SO}_{4}$ 0,3 $\mathrm{N}$ dan dididihkan di bawah pendingin, balik selama 30 menit. Setelah mendidih, ditambahkan $50 \mathrm{~mL}$ $\mathrm{NaOH}$ 1,5 N dan disaring kembali selama 30 menit. Cairan di dalam labu erlenmeyer disaring dengan kertas saring yang telah diketahui bobotnya. Penyaringan dilakukan menggunakan pompa vakum dan selanjutnya, dicuci dengan pompa vakum. Pencucian berturut-turut dengan $50 \mathrm{~mL}$ air panas dan $25 \mathrm{~mL}$ aseton. Residu beserta kertas saring dikeringkan sampai bobotnya konstan lalu dihitung dengan ditimbang.

\section{Karakteristrik fermentasi silase}

Konsentrasi N-NH3 menggunakan metode mikrodifusi Conway (1957). Bibir cawan Conway dan tutup di olesi dengan vaselin, Supernatan yang berasal dari proses fermentasi di ambil 1,0 mL kemudian di tempatkan pada salah satu ujung alur cawan Conway, Larutan $\mathrm{Na}_{2} \mathrm{CO}_{3}$ jenuh sebanyak 1,0 mL di tempatkan pada salah satu ujung cawan Conway bersebelahan dengan supernatant (tidak boleh campur), larutan asam borat berindikator sebanyak 1,0 mL di tempatkan dalam cawan kecil yang terletak di tengah cawan Conway, cawan Conway yang sudah diolesi vaselin di tutup rapat hingga kedap udara, larutan $\mathrm{Na}_{2} \mathrm{CO}_{3}$ di campur dengan supernatant hingga merata dengan cara menggoyang - goyangkan dan memiringkan cawan tersebut, setelah itu di biarkan selama 24 jam dalam suhu kamar, setelah 24 jam suhu kamar di buka, asam borat berindikator di titrasi dengan H2SO4 0,005 N sampai terjadi perubahan warna dari biru menjadi merah.

Konsentrasi total volatile fatty acid (T-VFA) menggunakan teknik destilasi uap atau Steam Destilation (General Laboratory Procedure 1966). Isi presscooker dengan aquadest sampai tanda MAX, kemudian pastikan air dari kran mengalir yang berfungsi sebagai pendingin, nyalakan kompor gas, sehingga aquadest yang ada dalam panci presscooker tersebut mendidih dan menghasilkan uap yang akan masuk ke tabung-tabung destilasi, dimana hal ini menandakan bahwa kita bisa memulai analisis VFA, supernatan yang sama dengan analisa NH3 di ambil sebanyak $5 \mathrm{~mL}$, kemudian di masukan kedalam tabung destilasi, tempatkan Erlenmeyer yang berisi $5 \mathrm{~mL} \mathrm{NaOH}$ 0,5 $\mathrm{N}$ dibawah selang tampungan. $1 \mathrm{~mL} \mathrm{H} 2 \mathrm{SO} 4$ 15\% di tambahkan ke tabung destilasi yang sudah ada larutan sampel, kemudian segera tutup penutup kacanya, bilas dengan aquadest secukupnya, uap air panas akan mendesak VFA dan akan terkondensasi dalam pendingin, air yang terbentuk di tampung labu Erlenmeyer yang

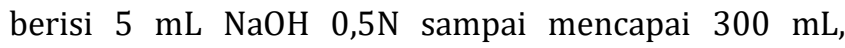
indikator PP (Phenol Pthalin) di tambah sebanyak 2 - 3 tetes dan di titrasi dengan $\mathrm{HCl} 0,5 \mathrm{~N}$ sampai warna titrat berubah dari merah menjadi merah muda seulas. Catatan: $\mathrm{HCl}$ 0,5 N sebagai titrant harus distandarisasi sehingga didapat konsentrasi dengan 4 digit dibelakang koma.

Nilai kecernaan silase secara invitro

Pengujian nilai kecernaan silase meliputi KCBK dan KCBO Tilley dan Terry (1963). Tabung fermentor yang telah di isi dengan 0,5 gr sampel, di tambahkan 40mL larutan McDougall. tabung di masukan ke dalam shaker bath dengan suhu $39^{\circ} \mathrm{C}$, kemudian diisi cairan rumen 10 $\mathrm{mL}$, tabung di kocok dengan di aliri $\mathrm{CO}_{2}$ selama 30 detik, cek pH ( 6,5 - 6,9) dan kemudian di tutup dengan karet berfentilasi, dan di fermentasi selama 48 jam. Setelah 48 jam, buka tutup karet tabung fermentor, teteskan 2 -3 tetes $\mathrm{HgCl} 2$ untuk membunuh mikroba. Masukan tabung fermentor ke dalam centrifuge, lakukan centrifuge dengan kecepatan 5.000 rpm selama 15 menit. Substrat akan terpisah menjadi endapan di bagian bawah dan supernatant yang bening berada di bagian atas, supernatan dibuang dan endapan hasil sentrifuge pada kecepatan $5.000 \mathrm{rpm}$ selama 15 menit di tambahkan $50 \mathrm{~mL}$ larutan pepsin-HCl 0,2\%. Campuran ini lalu di inkubasi kembali selama 48 jam tanpa tutup karet, sisa pencernaan di saring dengan kertas saring whatman no 41 (yang sudah diketahui bobotnya) dengan bantuan pompa vacum. Endapan yang ada di kertas saring di masukan ke dalam cawan porselen, setelah itu dimasukkan ke dalam oven $105^{\circ} \mathrm{C}$ selama 24 jam, setelah 24 jam, cawan porselen+kertas saring+residu dikeluarkan, dimasukkan kedalam eksikator dan ditimbang untuk mengetahui kadar bahan keringnya. Selanjutnya bahan dalam cawan di pijarkan atau di abukan dalam tanur listrik selama 6 jam pada suhu 450 - $600^{\circ} \mathrm{C}$, kemudian ditimbang untuk mengetahui kadar bahan organiknya, sebagai blanko di pakai residu asal fermentasi tanpa bahan pakan. 


\section{HASIL DAN PEMBAHASAN}

\section{Kualitas Fisik Silase}

Secara fisik, silase yang dihasilkan memiliki kualitas sangat baik dan tidak ada perbedaan karakteristik fisik silase campuran kombinasi yang dihasilkan dari kedua tanaman tersebut. Silase campuran kombinasi antara sorgum dan Indigofera dengan taraf yang berbeda memperlihatkan warna hijau sampai kuning kehijauan mendekati warna aslinya (Tabel 1). Hal ini sesuai dengan pendapat Saun \& Heinrichs (2008) yang menyatakan bahwa silase yang berkualitas baik akan berwarna hampir menyamai warna tanaman atau pakan sebelum diensilase. Silase yang baik berwarna kuning kehijauan (Melayu 2010). Menurut Despal et al. (2011) warna gelap pada silase mengindikasikan silase berkualitas rendah. Warna coklat muda diakibatkan karena hijau daun dari klorofil akan hancur selama proses ensilase, sedangkan warna putih mengindikasikan pertumbuhan jamur yang tinggi.

Silase yang berkualitas baik adalah silase yang memiliki aroma khas harum asam yang menandakan bahwa proses fermentasi di dalam silo berjalan dengan baik (Mannetje 1999). Jamur merupakan salah satu penyebab tanaman sorgum memiliki kualitas rendah. Pada penelitian ini jumlah jamur yang paling tinggi yaitu pada perlakuan sorgum hybrid 20 dengan pemberian Indigofera $15 \%$ sebesar $6,5 \%$ sehingga berada dalam tingkat berkualitas baik. Hal ini didukung oleh Davies (2007) yang berpendapat bahwa nilai optimum bagian terkontaminasi pada silase sebesar $10 \%$. Pembatasan

Tabel 1 Kualitas fisik nutrien silase kultivar sorgum (Sorghum bicolor) dengan penambahan taraf Indigofera sp. yang berbeda

\begin{tabular}{llcl}
\hline Perlakuan & \multicolumn{3}{c}{ Variabel } \\
\cline { 2 - 4 } & Warna & Aroma & $\begin{array}{c}\text { Jamur } \\
(\%)\end{array}$ \\
\hline S1G0 & Hijau & Vinegar & 6,3 \\
S1G1 & Hijau & Vinegar & 5,5 \\
S1G2 & Hijau & Vinegar & 6,5 \\
S1G3 & Hijau & Vinegar & 6,2 \\
S2G0 & Hijau & Vinegar & 6,2 \\
S2G1 & Hijau & Vinegar & 4,6 \\
S2G2 & Hijau & Vinegar & 6,1 \\
S2G3 & Hijau & Vinegar & 6,1 \\
S3G0 & Kuning kehijauan & Vinegar & 2,3 \\
S3G1 & Kuning kehijauan & Vinegar & 2,6 \\
S3G2 & Kuning kehijauan & Vinegar & 2,3 \\
S3G3 & Kuning kehijauan & Vinegar & 4,2 \\
S4G0 & Kuning kehijauan & Vinegar & 5,0 \\
S4G1 & Kuning kehijauan & Vinegar & 3,8 \\
S4G2 & Kuning kehijauan & Vinegar & 3,4 \\
S4G3 & Kuning kehijauan & Vinegar & 3,4 \\
\hline S1= Hybrid & 20; S2= 12FS9006; S3= 13FB7001; S4=12S49001; G0= \\
Indigofera 0\%; G1=Indigofera 10\%; G2=Indigofera 15\%; G3=Indigofera & & \\
20\%. & & &
\end{tabular}

http://journal.ipb.ac.id/index.php/jurnalintp
Tabel 2 Nilai pH nutrisi silase kultivar sorgum (Sorghum bicolor) dengan penambahan taraf Indigofera sp. yang berbeda.

\begin{tabular}{lllll}
\hline Jenis Sorgum & \multicolumn{4}{c}{ Level pemberian Indigofera sp. } \\
\cline { 2 - 5 } & G0 & G1 & G2 & G3 \\
\hline S1 : Hybrid 20 & 3,7 & 3,9 & 3,4 & 4,0 \\
S2 : 12FS9006 & 3,9 & 3,9 & 4,0 & 4,5 \\
S3 : 13FB7001 & 4,0 & 4,2 & 4,2 & 4,1 \\
S4 : 12S49001 & 3,8 & 4,0 & 4,3 & 4,1 \\
\hline
\end{tabular}

$\mathrm{G0}=$ Indigofera $0 \% ; \mathrm{G1}=$ Indigofera 10\%; G2= Indigofera 15\%; $\mathrm{G} 3=$ Indigofera $20 \%$.

suplai oksigen yang kurang optimal berkaitan dengan ukuran partikel dari bahan. Tingkat kerusakan silase pakan in situ yang berkualitas baik yaitu $<1,25 \%$ karena berada dibawah nilai kisaran kerusakan yang dapat ditoleransi akibat pembusukan, nilai itu berkisar 4-12\% (Telleng 2017).

\section{pH Silase Sorgum dengan Penambahan Indigofera sp.}

Tabel 2 menunjukkan $\mathrm{pH}$ silase sorgum dengan penambahan Indigofera sp. Bakteri Asam Laktat membutuhkan karbohidrat larut air hingga menyebabkan penurunan pH sampai 3,5 (Muck \& Bolsen 1991). Tingginya pH dipicu oleh terpaparnya silase terhadap oksigen yang terlalu lama, menyebabkan kondisi aerob. Kondisi aerob ini lebih banyak memfermentasi karbohidrat terlarut menjadi panas daripada produksi asam. Saat kondisi asam, asam laktat dan asetat lebih mampu membatasi pertumbuhan mikroorganisme pembusuk (Muck \& Bolsen 1991). Pertumbuhan Clostridia akan memfermentasikan karbohidrat terkarut menjadi asam butirat yang akan menaikan derajat keasaman atau nilai pH. Telleng (2017) menyatakan bahwa $\mathrm{pH}$ rendah dalam silase akan sulit tercapai jika produksi asam laktat rendah dan terjadi reaksi yang tidak diinginkan seperti terbentuknya asam butirat sebagai hasil fermentasi oleh bakteri Clostridia sehingga kualitas silase tidak bagus.

\section{Komposisi Nutrien Silase Sorgum dengan Penambahan Indigofera}

Pada Tabel 3 menunjukkan kadar air yang terendah yaitu terdapat pada silase jenis sorgum hybrid 20 dengan rataan sebesar $72,84 \%$ dan rataan yang tertinggi terdapat pada pada kultivar sorgum 13FB7001 dengan rataan sebesar 80,39\%. Kandungan air silase dipengaruhi oleh jenis sorgum dan umur panen, semakin lama pemanenan maka akan meningkatkan kadar air dan terjadi penurunan kandungan bahan kering (Ardiansyah 2016). Kandungan air dalam silase banyak berkurang disebabkan adanya peningkatan kandungan BK setelah 
proses fermentasi yang diduga karena lamanya waktu pengeringan dalam oven.

Kandungan protein kasar (PK) silase cenderung meningkat dilihat dari masing-masing kultivar sorgum baru yang semakin tinggi sampai level pemberiaan Indigofera sp. $15 \%$. Hasil pengamatan dari Tabel 3 dibawah ini menunjukkan bahwa sorgum hybrid 20 memiliki kualitas lebih baik dari jenis sorgum lainnya dengan rataan sebesar 7,18\%. Perbedaan kandungan protein kasar ini dipengaruhi oleh jenis tanaman, kondisi lingkungan, dan umur pemanenan hijauan tersebut (Jayanegara et al. 2009). Pada hijauan yang masih muda mengandung protein yang tinggi sehingga terjadinya fermentasi protein (Ristianto et al. 1979). Santoso \& Hariadi (2008) menambahkan bahwa penurunan kandungan protein kasar terjadi akibat adanya degradasi protein oleh enzim protease dan Clostridia selama proses fermentasi.

Kandungan serat kasar yang paling tinggi yaitu pada kultivar sorgum hybrid 20 sebesar 38,39\% (Tabel 3). Kandungan serat kasar ini yaitu komponen dinding sel tanaman yang terdiri dari selulosa dan hemiselulosa yang dilapisi lignin dan silika. Perubahan serat kasar ini

Tabel 3 Komposisi nutrien silase sorgum (Sorghum bicolor) dengan penambahan Indigofera sp. pada taraf yang berbeda.

\begin{tabular}{|c|c|c|c|c|c|c|}
\hline \multirow[b]{2}{*}{ Perlakuan } & \multicolumn{5}{|c|}{ Komposisi Nutrien (\% BK) } & \multirow[b]{2}{*}{ BETN } \\
\hline & Air & Abu & $\begin{array}{l}\text { Lemak } \\
\text { kasar }\end{array}$ & $\begin{array}{l}\text { Protein } \\
\text { kasar }\end{array}$ & $\begin{array}{l}\text { Serat } \\
\text { kasar }\end{array}$ & \\
\hline S1G0 & 69,62 & 2,74 & 2,36 & 5,53 & 43, & 45,95 \\
\hline S1G1 & 82,65 & 2,70 & 2,41 & 6,44 & 32,03 & 56,43 \\
\hline S1G2 & 81,34 & 3,98 & 0,60 & 9,33 & 35,09 & 51,00 \\
\hline S1G3 & 57,76 & 6,39 & 4,45 & 7,44 & 43,04 & 38,68 \\
\hline $\bar{x}$ & 72,84 & 3,95 & 2,45 & 7,18 & 38,39 & 48,01 \\
\hline Sdv & 11,64 & 1,73 & 1,57 & 1,63 & 5,73 & 7,55 \\
\hline S2G0 & 72,30 & 4,92 & 2,52 & 4,04 & 37,58 & 50,94 \\
\hline S2G1 & 72,88 & 6,24 & 3,21 & 7,51 & 38,34 & 44,70 \\
\hline S2G2 & 77,62 & 5,24 & 2,31 & 7,37 & 32,72 & 52,36 \\
\hline S2G3 & 74,94 & 5,20 & 2,39 & 6,34 & 39,35 & 46,71 \\
\hline $\bar{x}$ & 74,43 & 5,40 & 2,61 & 6,31 & 37,00 & 48,68 \\
\hline Sdv & 2,41 & 0,58 & 0,41 & 1,60 & 2,94 & 3,58 \\
\hline S3G0 & 84,63 & 4,61 & 2,33 & 4,44 & 29,44 & 59,18 \\
\hline S3G1 & 73,74 & 6,82 & 3,49 & 7,78 & 31,90 & 50,01 \\
\hline S3G2 & 76,31 & 6,91 & 3,01 & 8,20 & 30,36 & 51,51 \\
\hline S3G3 & 86,87 & 5,87 & 2,18 & 5,84 & 29,77 & 56,35 \\
\hline $\bar{x}$ & 80,39 & 6,05 & 2,75 & 6,57 & 30,37 & 54,26 \\
\hline Sdv & 6,35 & 1,07 & 0,61 & 1,75 & 1,09 & 4,25 \\
\hline S4G0 & 79,42 & 4,75 & 1,60 & 2,23 & 37,65 & 53,78 \\
\hline S4G1 & 76,60 & 3,83 & 2,53 & 3,46 & 36,25 & 53,93 \\
\hline S4G2 & 68,96 & 5,50 & 3,77 & 6,38 & 36,48 & 47,87 \\
\hline S4G3 & 76,29 & 4,67 & 2,01 & 4,51 & 25,97 & 62,85 \\
\hline $\bar{x}$ & 75,32 & 4,68 & 2,48 & 4,14 & 34,09 & 54,61 \\
\hline Sdv & 4,46 & 0,68 & 0,94 & 1,76 & 5,45 & 6,18 \\
\hline
\end{tabular}

terjadi karena kemampuan hidrolisis karbohidrat, selama proses ensilase karbohidrat tanaman dirombak menjadi asam lemak terbang yaitu asam laktat, asam asetat, asam butirat, asam karbonat serta alkohol dalam jumlah kecil (Ensminger \& Olentin 1978). Proses asimilasi $\mathrm{N}$ mampu menurunkan kandungan serat kasar yang menyebabkan persediaan $\mathrm{N}$ cukup untuk pembentukan protein (Sanchez et al. 2010). Bertambahnya komposisi Indigofera sp. menghasilkan serat kasar yang lebih rendah, hal ini didukung oleh Sumarsono (2006) bahwa leguminosa pada pertanaman campuran secara nyata menurunkan kadar serat kasar. Rataan kandungan BETN silase campuran sorgum dan Indigofera sp. pada masing-masing varietas sorgum hybrid 20, sorgum 12FS9006, 13FB7001, dan 12S49001 sebesar $48,01 \%$, 48,68\%, 54,26\%, dan 54,61\%.

\section{Karakteristrik Fermentasi Silase dan Nilai kecernaan Silase secara In Vitro}

Amonia adalah sumber nitrogen yang utama dan sangat penting untuk sintesis protein mikroba rumen. Berdasarkan hasil pengamatan dari Tabel 4, dapat dilihat

Tabel 4 Nilai NH3, total VFA, KCBK, dan KCBO silase sorgum (Sorghum bicolor) dengan penambahan taraf Indigofera sp. yang berbeda

\begin{tabular}{|c|c|c|c|c|}
\hline Perlakuan & $\begin{array}{l}\mathrm{NH}_{3} \\
(\mathrm{mM})\end{array}$ & $\begin{array}{l}\text { Total } \\
\text { VFA } \\
(\mathrm{mM})\end{array}$ & $\begin{array}{l}\text { KCBK } \\
(\%)\end{array}$ & $\begin{array}{l}\text { KCBO } \\
(\%)\end{array}$ \\
\hline S1G0 & 6,57 & 35,54 & 47, & 47,40 \\
\hline S1G1 & 7,13 & $j 8,43$ & 48,57 & 48,21 \\
\hline S1G2 & 7,61 & 77,04 & 57,66 & 57,22 \\
\hline S1G3 & 7,93 & 77,66 & 45,77 & 44,87 \\
\hline $\bar{x}$ & 7,31 & 72,17 & 49,95 & 49,43 \\
\hline Sdv & 0,59 & 6,10 & 5,28 & 5,39 \\
\hline S2G0 & 7,27 & 36,63 & 50,33 & 49,65 \\
\hline S2G1 & 8,23 & $\exists 2,02$ & 52,34 & 51,31 \\
\hline $\mathrm{S} 2 \mathrm{G} 2$ & 8,58 & 33,15 & 56,19 & 55,09 \\
\hline S2G3 & 8,96 & 03,22 & 46,12 & 44,60 \\
\hline$x$ & 8,26 & 33,76 & 51,25 & 50,16 \\
\hline Sdv & 0,72 & 6,92 & 4,19 & 4,35 \\
\hline S3G0 & 6,22 & 71,63 & 36,74 & 36,36 \\
\hline S3G1 & 7,33 & 75,06 & 37,52 & 36,79 \\
\hline S3G2 & 8,05 & 36,35 & 45,99 & 45,25 \\
\hline S3G3 & 8,58 & 05,94 & 44,62 & 43,99 \\
\hline $\bar{x}$ & 7,55 & 37,25 & 41,22 & 40,60 \\
\hline Sdv & 1,02 & $L 6,58$ & 4,76 & 4,68 \\
\hline S4G0 & 6,50 & 32,87 & 45,73 & 44,63 \\
\hline S4G1 & 7,10 & 74,72 & 47,72 & 46,65 \\
\hline S4G2 & 7,47 & 76,49 & 48,30 & 47,66 \\
\hline S4G3 & 7,88 & 37,52 & 50,92 & 49,82 \\
\hline$x$ & 7,24 & 75,40 & 48,17 & 47,19 \\
\hline Sdv & 0,59 & 10,09 & 2,14 & 2,16 \\
\hline
\end{tabular}

S1= Hybrid 20; S2= 12FS9006; S3= 13FB7001; S4=12S49001; G0= Indigofera 0\%; G1= Indigofera 10\%; G2=Indigofera 15\%; G3= Indigofera $20 \%$. 


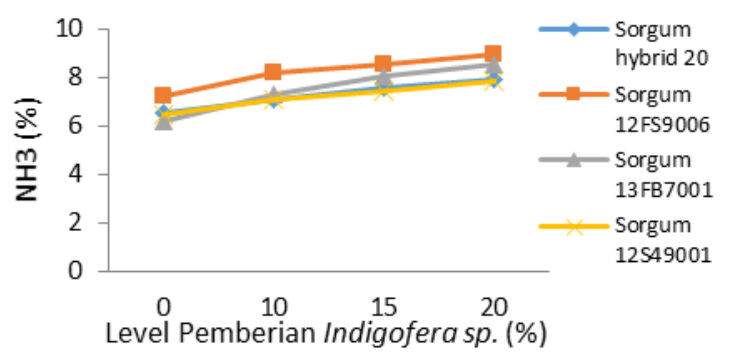

Gambar 1 NH3 silase sorgum dengan penambahan Indigofera sp. pada level yang berbeda

bahwa setiap kultivar sorgum terdapat peningkatan kadar NH3 seiring bertambahnya level pemberian Indigofera sp. di dalam campuran silase.

Kultivar sorgum 12FS9006 memiliki rataan kadar NH3 yang paling tinggi yaitu 8,26\%. Semakin tinggi level penambahan Indigofera sp. dalam campuran akan menyebabkan semakin tingginya kadar NH3 yang dihasilkan. Hasil ini menunjukkan bahwa kombinasi antara keempat kultivar sorgum dengan penambahan Indigofera sp. mampu menghasilkan konsentrasi $\mathrm{NH} 3$ yang berada pada rentang optimal sebesar 6-21 Mm yang sesuai dengan pendapat McDonald et al. (2002).

Tingginya kadar NH3 disebabkan kandungan prekursor $\mathrm{N}$ pada pakan tersebut relatif tinggi, sehingga ketersediaan $\mathrm{N}$ bagi mikroba yang mendegradasi pakan berkembang cukup baik. Konsentrasi amonia yang tinggi disebabkan oleh pemecahan protein yang berlebihan dan lambatnya penurunan $\mathrm{pH}$ serta pertumbuhan Clostridium atau enterobacteria. Protein pakan akan mengalami deaminasi didalam rumen sehigga menghasilkan $\mathrm{NH} 3$ dan $\mathrm{CO} 2$, semakin tinggi degradabilitas protein semakin tinggi pula produksi NH3 di dalam rumen. Sutardi (1979) menyatakan bahwa konsentrasi NH3 dalam rumen dipengaruhi oleh tingkat protein sampel, sumber protein dan kelarutannya. Protein yang terdapat di dalam Indigofera sp. merupakan protein yang mudah didegradasi oleh mikroba rumen (Suharlina 2016).

Volatile Fatty Acid (VFA) adalah produk dari metabolisme karbohidrat di dalam rumen yang dibantu oleh mikroba tertentu. Berdasarkan hasil pengamatan Tabel 4 menunjukkan bahwa kultivar sorgum yang

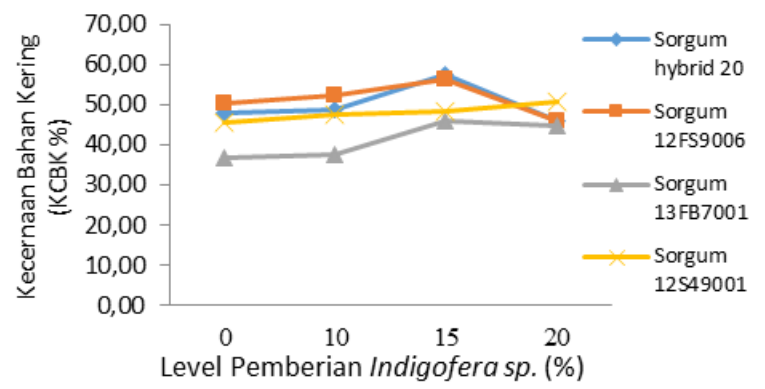

Gambar 3 Kecernaan bahan kering silase sorgum dan penambahan Indigofera sp. pada level yang berbeda

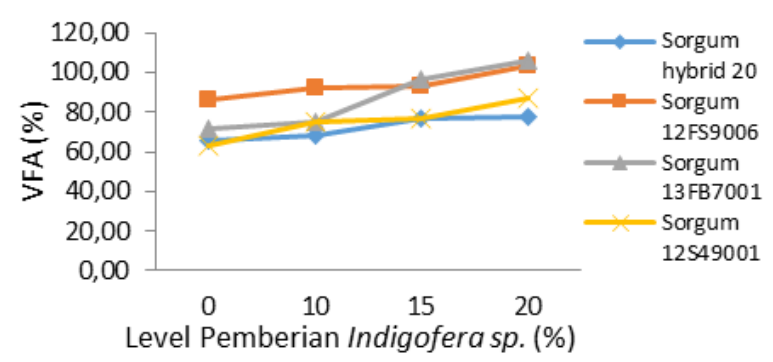

Gambar 2 VFA silase sorgum dengan penambahan Indigofera sp. pada level yang berbeda

paling tinggi yaitu kultivar sorgum 12FS9006 dengan rataan sebesar 93,76\%. Sama halnya dengan konsentrasi NH3 dimana terjadi peningkatan VFA di masing-masing jenis kultivar sorgum dengan level pemberian Indigofera sp. yang bertambah. Produksi normal VFA berkisar 70150 mM (McDonald et al. 2010). Menurut Telleng (2017), konsentrasi total VFA dari pergantian pakan komplit berbasis rumput gajah dengan pakan berbasis sorgumIndigofera sp. berkisar 92,58-142,38 mM.

Tingginya VFA cairan rumen pada silase campuran sorgum dan Indigofera sp. dipengaruhi oleh sumber energi mikroba untuk mensintesis protein mikroba dan pertumbuhan sel didalam tubuhnya (Nurhayati 2008). VFA yang tinggi menunjukkan peningkatan kandungan protein dan karbohidrat mudah larut dalam pakan. Pada ternak ruminansia sumber energi utama adalah VFA hasil fermentasi karbohidrat oleh mikroba rumen. Lebih rendahnya nilai VFA berkaitan dengan jumlah karbohidrat yang sulit terdegradasi oleh mikroba dan terhambatnya penyerapan monosakarida oleh mikroba rumen. Jayanegara et al. (2006) menyatakan bahwa rendahnya VFA disebabkan karena adanya penyerapan monosakarida yang terhambatnya proses fermentasi. Proses fermentasi merupakan proses penyediaan energi bagi mikroba rumen, maka rendahnya VFA mencerminkan rendahnya energi yang tersedia bagi mikroba rumen.

Kecernaan in vitro bahan kering pada penelitian ini berkisar antara 36,74\% - 57,66\%. Hal ini sesuai dengan pernyataan Yusmadi (2008), kecernaan bahan kering in vitro silase pakan komplit yaitu sebesar 54,22 \%. Telleng (2017) mendapatkan rataan kecernaan bahan kering

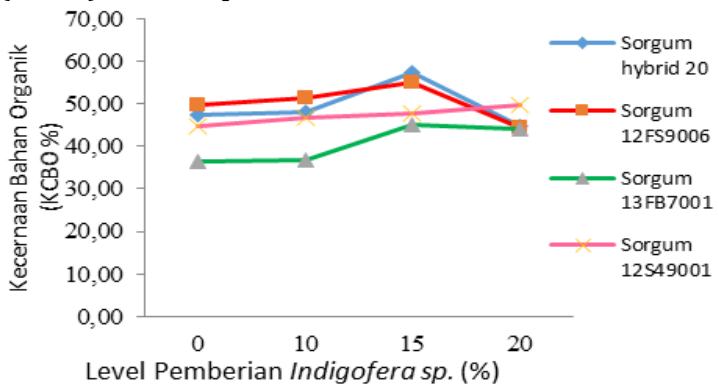

Gambar 4 Kecernaan bahan organik silase sorgum dan penambahan Indigofera sp. pada level yang berbeda 
pergantian pakan komplit rumput gajah dengan pakan berbasis sorgum - Indigofera sebesar 57,67\% - 69,31\%. Tingginya kecernaan bahan kering pada tiap jenis sorgum dengan level pemambahan Indigofera yang berbeda sejalan dengan meningkatnya VFA dan N-NH3. VFA dan N-NH3 merupakan produk fermentasi dari karbohidrat dan protein pakan yang dibutuhkan oleh mikroba rumen, sehingga semakin optimal pertumbuhan mikroba akan meningkatkan kecernaan bahan kering.

Suharlina (2016) menyatakan bahwa Indigofera sp. memiliki kandungan protein kasar yang tinggi dengan serat kasar yang rendah, sehingga peningkatan taraf Indigofera sp. ke dalam ransum akan memicu terjadinya peningkatan kecernaan rumen kambing perah. Kandungan dan kualitas nutrien bahan pakan menentukan kecernaan suatu bahan pakan. Ketersediaan karbohidrat maupun protein dalam bahan pakan berperan besar sebagai proliferasi dan proses fermentasi oleh mikroba rumen karena karbohidrat digunakan sebagai sumber energi dan sumber kerangka karbon, sedangkan protein digunakan sebagai sumber nitrogen untuk menyusun tubuh mikroba rumen. Ketersediaan energi ini merupakan faktor esensial dalam mempercepat pertumbuhan dan proliferasi mikroba rumen untuk mendegradasi komponen organik bahan pakan meningkat, sehingga terjadi peningkatan kecernaan bahan pakan (Telleng 2017).

Kecernaan bahan kering dan kecernaan bahan organik silase campuran kombinasi sorgum dan Indigofera sp. pada level pemberian yang berbeda dapat dilihat pada Gambar 3.

Kecernaan bahan organik silase campuran kombinasi sorgum dan Indigofera sp. tidak jauh berbeda dengan kecernaan bahan kering (Tabel 4). Kecernaan in vitro bahan organik pada penelitian ini berkisar antara 36,36 57,22\%. Telleng (2017) dalam penelitiannya terkait pergantian pakan komplit menghasilkan kecernaan in vitro bahan organik berkisar 56,92\% - 67,90\%. Kecernaan bahan organik dipengaruhi oleh beberapa komponen antara lain kandungan protein kasar dan kandungan serat, baik NDF, ADF maupun hemiselulosa (Jayanegara et al. 2009). Peningkatan kecernaan juga dipengaruhi oleh adanya perbaikan kemampuan mikroba rumen dan perbaikan proses metabolisme mikroba untuk mendegradasi komponen organik bahan pakan semakin meningkat. Rahmawati (2001) menyatakan bahwa degradasi bahan organik sangat dibutuhkan oleh ternak guna memenuhi kebutuhan hidup pokok dan produksi. Berdasarkan grafik menunjukkan bahwa nilai KCBK dan KCBO yang tinggi yaitu pada kultivar sorgum 12FS9006, hal ini terjadi karena kenaikan nilai kecernaan disetiap penambahan level pemberian Indigofera sp. khususnya level 15\%. Hasil pengukuran kecernaan bahan pakan baik kering maupun bahan organik sangat diperlukan untuk mengetahui banyaknya zat gizi yang diserap oleh tubuh dan menunjukkan tingkat kualitas dari bahan pakan tersebut.

\section{SIMPULAN}

Kadar air, kadar abu dan lemak kasar silase kultivar sorgum 13FB7001 dengan penambahan Indigofera sp. lebih tinggi dibandingkan kultivar sorgum hybrid 20, 12FS9006, dan 12S49001. Silase kultivar sorgum hybrid 20 dengan penambahan Indigofera sp. memiliki kandungan protein kasar dan serat kasar yang lebih tinggi dibandingkan sorgum 13FB7001, 12FS9006, dan 12S49001. Kultivar sorgum 12FS9006 menghasilkan silase yang berkualitas baik secara fermentatif $(\mathrm{pH}, \mathrm{N}$ NH3, VFA, KCBK, dan KCBO). Level pemberian Indigofera sp. $15 \%$ cenderung memberikan kualitas silase keempat kultivar sorgum yang lebih tinggi dibandingkan level $0 \%$, $10 \%$ dan 20\%. Silase kultivar baru sorgum dengan pemberian Indigofera sp. dapat meningkatkan kandungan nutrien, dan kualitas silase.

\section{DAFTAR PUSTAKA}

Abdullah L \& Suharlina. 2010. Herbage yield and quality of two vegetative parts of Indigofera at different time of first regrowth defoliation. Media Peternakan. 1(33): 44-49.

Abdullah L. 2014. Mewujudkan konsentrat hijau (green concentrate) dalam industri baru pakan untuk mendorong kemandirian pakan dan daya saing peternakan nasional [orasi Ilmiah]. Bogor (ID): Institut Pertanian Bogor.

Ardiansyah. 2016. Kualitas dan fermentabilitas in vitro campuran legum dan silase sorgum varietas Citayam dan galur BMR 3.6 pada umur panen berbeda [Tesis]. Bogor (ID): Institut Pertanian Bogor.

Davies D. 2007. Improving silage quality and reducing $\mathrm{CO}_{2}$ emissions. Agricultural and Food Science. 22:93-107

Despal, Permana IG, Safarina SN \& Tatra AJ. 2011. Penggunaan berbagai sumber karbohidrat terlarut air untuk meningkatkan kualitas silase daun rami. Media Peternakan. 34 (1):69-76.

[Direktorat Pakan Ternak]. 2011. Pedoman Umum Pengembangan Lumbung Pakan Ruminansia. Jakarta: Direktorat Jenderal Peternakan dan Kesehatan Hewan

Ensminger M E \& Olentine C G. 1978. Feeds and Nutrition Complete. California US: The Ensminger Publishing Company

Jayanegara A, Tjakradidjaja AS, \& Sutardi T. 2006. Fermentabilitas dan kecernaan in vitro ransum limbah agroindustri yang disuplementasi kromium anorganik dan organik. Media Peternakan. 29(2):54-62.

Jayanegara A, Sofyan A, Makkar HPS, \& Becker K. 2009. Kinetika produksi gas, kecernaan bahan organik dan produksi gas metan in vitro pada hay dan jerami yang disuplementasi hijauan mengandung tannin. Media Peternakan. 32(2):120-129.

Mannetje LT. 1999. Silage making in the tropics with particular emphasis on smallholders. Proceedings of the FAO Electronic Conference on Tropical Silage. Rome (IT): FAO

McDonald P, Edwards RA, Greenhalgh JFD \& Morgan CA. 2002. Animal Nutrition. $6^{\text {th }}$ Ed. England (UK): Harlow.

McDonald P, Edwards RA, Greenhalgh JFD, Morgan CA, Sinclair LA, \& Wilkinson RG. 2010. Animal Nutrition. $7^{\text {th }}$ Ed. England (UK): Prentice Hall, Pearson. Harlow, 
Melayu SR. 2010. Pembuatan Silase Hijauan. Padang (ID): Universitas Andalas

Muck RE \& Bolsen KK. 1991. Silage preservation and silage additive products in hay and silage management in North America. KK Bolsen, JJ Baylor, and McCullough (ed). Iowa (US): Nat FeedIngred Assoc, West Des Moines.

Mugiawati, R.E. 2013. Kadar air dan pH silase rumput gajah pada hari ke-21 dengan penambahan jenis aditif dan bakteri asam laktat. Jurnal Ternak Ilmiah. 1 (1): 201-207.

Nur'aini. 2017. Evaluasi nutrien dan fermentabilitas in vitro campuran legum Indigofera sp. dan kultivar baru tanaman sorgum (Sorghum bicolor) [skripsi]. Bogor (ID): Institut Pertanian Bogor.

Nurhayati MD. 2008. Kajian in vitro fermentabilitas dan degradabilitas ransum komplit kombinasi rumput lapang, konsentrat dan suplemen pakan multinutrien [skripsi]. Bogor (ID): Institut Pertanian Bogor.

Rahmawati I. G. A. W. D. 2001. Evaluasi in vitro kombinasi lamtoro merah (Acacia villosa) dan gamal (Gliricidia maculate) untuk meningkatkan kualitas pakan pada ternak domba [skripsi]. Bogor (ID): Institut Pertanian Bogor.

Reiber C, Schultze-Kraft R, Peters M, Lentes P, \& Hoffmann V. 2010. Promotion and adoption of silage technologies in droughtconstrained areas of Honduras. Tropical Grassland. 44:231-245.

Ristianto, U., Soekanto, L \& Harlianti, A. 1979. Percobaan Silase. Laporan Konservasi Hijauan Makanan Ternak, Jawa Tengah. Yogyakarta. ID) : Direktorat Bina Produksi, Direktorat Jenderal Peternakan, Departemen Pertanian dan Fakultas Peternakan Universitas Gadjah Mada.

Sanchez DGR, Silva JTE, Gil AP, Corona JSS, Wong JAC \& Mascoro G. 2010. Forage yield and quality of intercropped corn and soybean in narrow strip. Spanish Journal Agricultural Reserch. 8 (3): 713-721.

Santoso B, Hariadi B. 2008. Komposisi kimia, degradasi nutrien dan produksi gas metana in vitro rumput tropik yang diawetkan dengan metode silase dan hay. Media Peternakan. 31(2):128-137.

Sirappa MP. 2003. Prospek Perkembangan Sorgum di Indonesia sebagai komoditas alternative untuk pangan, pakan, dan industri. Jurnal Litbang Pertanian. 22: 133-140.

Suharlina. 2010. Peningkatan produktivitas Indigofera zollingeriana sebagai pakan berkualitas tinggi melalui aplikasi pupuk organik cair [tesis]. Bogor (ID): Institut Pertanian Bogor.

Suharlina. 2016. Pemanfaatan dan pengembangan ransum berbasis Indigofera zollingeriana berkualitas untuk kambing perah [disertasi]. Bogor (ID): Institut Pertanian Bogor.

Sumarsono. 2006. Peran tanaman pakan dalam intervensi pertanian berwawasan lingkungan. Makalah utama disajikan dalam silaturahmi ilmiah internal Semarang (ID): Fakultas Peternakan Universitas Diponegoro.

Sutardi T. 1979. Ketahanan protein bahan makanan terhadap degradasi mikroba rumen dan manfaatnya bagi peningakatan produktivitas ternak. Prosiding Seminar Penelitian dan Penunjang Peternakan. Bogor (ID): LPP Institut Pertanian Bogor.

Telleng MM. 2017. Penyediaan pakan berkualitas berbasis sorgum (Sorghum bicolor) dan Indigofera (Indigofera sollingeria) dengan pola tanam tumpangsari [disertasi]. Bogor (ID) : Institut Pertanian Bogor.

Utomo R. 2015. Konservasi Hijauan Pakan dan Peningkatan Kualitas Bahan Pakan Berserat Tinggi. Yogyakarta (ID): Gadjah Mada University Press.

Yusmadi. 2008. Kajian mutu dan palatabilitas silase dan hay ransum komplit berbasis sampah organik primer pada kambing peranakan etawah [tesis]. Bogor ( ID): Institut Pertanian Bogor 